\title{
DEMONSTRASI PENGENALAN VARIASI MENU DIET DIABETES MELLITUS BAGI PENDERITA DIABETES MELLITUS TIPE 2
}

\author{
Zuhria Ismawanti $^{1}$, Nastitie Cinintya Nurzihan ${ }^{1}$, Nining Prastiwi ${ }^{2}$ \\ 1Program Studi Gizi Program Sarjana, Fakultas Ilmu Kesehatan, Universitas Kusuma Husada Surakarta \\ 2Program Studi Promosi Kesehatan Program Sarjana Terapan, Fakultas Ilmu Kesehatan, Universitas \\ Kusuma Husada Surakarta \\ riazuhria27@gmail.com
}

\begin{abstract}
Diabetes mellitus (DM) is a disease that an unhealthy lifestyle can cause. DM treatment has four pillars: education, DM diet management, physical activity, and drug management. The recommended DM dietary arrangement is almost the same as the recommended diet in general, namely balanced nutrition following calorie needs; however, DM sufferers will emphasize regularly eating in terms of eating schedules, types of food, and amount of food. Based on these problems, it is necessary to introduce variations in the diabetes mellitus diet menu for type 2 diabetes mellitus sufferers. Pre-test and post-test are carried out to determine the level of understanding. The method was to introduce an introduction to the diabetes mellitus diet menu variation for people with diabetes type 2. As many as 25 people participated in this activity from beginning to end. Based on the evaluation results using the post-test value, it shows that there is an increase in knowledge and skills regarding the variation of the type 2 DM diet. To prevent complications of type $2 \mathrm{DM}$.
\end{abstract}

Keywords: Diabetes Mellitus type 2, demonstration, diabetes mellitus diet

\begin{abstract}
Abstrak
Diabetes Melitus (DM) merupakan salah satu penyakit yang dapat disebabkan oleh gaya hidup yang tidak sehat. Perawatan DM memiliki empat pilar dalam penatalaksanaannya, yaitu edukasi, pengaturan diet DM, aktifitas fisik dan manajemen obat. Pengaturan diet DM yang dianjurkan hampir sama dengan anjuran diet pada umumnya yaitu gizi seimbang yang sesuai dengan kebutuhan kalori, akan tetapi penderita DM akan ditekankan keteraturan makan dalam hal jadwal makan, jenis makanan dan jumlah makanan. Berdasarkan permasalahan tersebut diperlukan adanya demonstrasi pengenalan variasi menu diet diabetes melitus bagi penderita DM tipe 2. Kegiatan ini dilakukan untuk meningkatkan pengetahuan tentang variasi menu diet diabetes melitus pada penderita DM tipe 2. Pre-test dan post-test dilakukan untuk mengetahui tingkat pemahaman mengenai demonstrasi yang diberikan. Metode yang dilakukan adalah memberikan demonstrasi pengenalan variasi menu diet diabetes melitus bagi penderita DM tipe 2. Sebanyak 25 orang mengikuti kegiatan ini dari awal hingga akhir. Berdasarkan hasil evaluasi menggunakan nilai post test menunjukkan bahwa adanya peningkatan pengetahuan dan keterampilan mengenai variasi menu diet DM tipe 2. Dengan demikian dapat disimpulkan bahwa terdapat peningkatan pengetahuan dan kesadaran dalam perbaikan pola, porsi dan pemilihan bahan makanan yang dapat digunakan dalam pembuatan diet diabetes melitus, sehingga dapat mencegah terjadinya komplikasi DM tipe 2.
\end{abstract}

Kata kunci: Diabetes melitus tipe 2, demontrasi, diet diabetes melitus. 
PENDAHULUAN

WHO memprediksi kenaikan jumlah penyandang Diabetes melitus (DM) di Indonesia dari 8,4 juta pada tahun 2000 menjadi sekitar 21,3 juta pada tahun 2030 (Perkeni, 2015). Jumlah penderita DM tahun 2018 di Indonesia pada usia dewasa sekitar 12.191.564 jiwa atau 6.9\% jumlah penduduk usia dewasa (Pusdatin Kemenkes RI, 2018). Jumlah tersebut merupakan angka yang perlu menjadi perhatian tidak hanya untuk pemerintah, namun juga untuk masyarakat.

DM tergolong suatu penyakit metabolik yang ditandai dengan hiperglikemia karena kelainan sekresi insulin, kerja insulin atau keduaduanya. Hiperglikemia adalah suatu kondisi terjadi peningkatan kadar glukosa dalam darah. Hiperglikemia merupakan penanda khas penyakit diabetes mellitus (DM), meskipun juga mungkin didapatkan pada beberapa keadaan yang lain (Perkeni, 2015).

DM merupakan salah satu penyakit yang dikarenakan gaya hidup yang tidak sehat. Perawatan DM menurut Perkeni (2015) memiliki empat pilar dalam penatalaksanaannya, yaitu edukasi, pengaturan diet DM, aktifitas fisik dan manajemen obat. Pada kegiatan pengabdian masyarakat ini intervensi yang digunakan untuk merawat keluarga dengan penderita DM adalah pengaturan diet DM. Pengaturan diet DM yang dianjurkan hampir sama dengan anjuran diet pada umumnya yaitu gizi seimbang yang sesuai dengan kebutuhan kalori, akan tetapi penderita DM difokuskan terkait dengan keteraturan dalam jadwal makan, jenis makanan dan jumlah makanan. Makanan bagi penderita DM juga perlu memperhatikan indeks glukosa untuk menjaga kestabilan gula darah.
Demonstrasi pengenalan variasi menu diet diabetes melitus ini sebagai sarana untuk lebih mengetahui berbagai macam variasi menu yang dapat digunakan sebagai acuan diet atau pengaturan pola makan untuk penderita DM tipe 2. Kegiatan pengabdian kepada masyarakat mengenai demonstrasi pengenalan variasi menu diet diabetes melitus untuk penderita diabetes melitus tipe 2 belum pernah dilakukan di wilayah kerja Puskesmas Gambirsari.

Banyak orang yang menyadari bahwa DM yang terjadi adalah karena pola hidup yang tidak sehat, terutama makan-makanan yang manis. Namun keluarga tidak mengetahui bahwa yang terpenting pada diet DM adalah bukan mengurangi makanan manis, tetapi mengatur pola makan agar sesuai dengan kebutuhan kalori dan menghindari makanan dengan indeks glukosa yang tinggi. Pengetahuan keluarga mengenai cara mengatur dan menyusun menu DM, aktivitas fisik yang masih rendah, dan keluarga hanyak mengetahui cara merawat DM hanya sebatas minum obat. Oleh karena itu diperlukan intervensi dengan demonstrasi pengenalan variasi menu diet diabetes melitus bagi penderita DM tipe 2.

\section{METODE}

Kegiatan pengabdian kepada masyarakat ini dilakukan dengan metode demonstrasi, ceramah dan diskusi serta tanya jawab.

Demonstrasi variasi menu diet diabetes mellitus sebagai sarana untuk lebih mengetahui berbagai jenis menu yang dapat digunakan dalam diet diabetes mellitus. Metode ceramah digunakan untuk menyampaikan materi atau topik mengenai variasi diet diabetes melitus sehingga sehingga seperta lebih mudah dan memahami dan 
mempelajari pesan yang disampaikan. Diskusi dan tanya jawab dapat membantu masyarakat menanyakan halhal yang belum dipahami untuk lebih memaksimalkan pengetahuan tentang variasi menu diet diabetes mellitus bagi penderita DM tipe 2.

Alat dan bahan yang digunakan adalah laptop, LCD, makanan riil, poster, leaflet diet diabetes melitus, contoh menu makanan dan kuesioer.

Tahapan kegiatan pengabdian kepada masyarakat ini dimulai dengan pertemuan dengan pihak puskesmas yang bertujuan untuk berkoordinasi terkait pelaksanaan kegiatan pengabdian kepada masyakarat. Persiapan alat dilakukan Bersama dengan tim pengabdian. Sedangkan untuk proses pelaksanaan akan dilaksanakan sesuai dengan kesepakan dengan pihak puskesmas. Evaluasi dan monitoring dilakukan setelah proses kegiatan melalui formulir post test.

\section{HASIL DAN PEMBAHASAN}

Kegiatan pengabdian kepada masyarakat yang dilakukan oleh program studi sarjana gizi Universitas Kusuma Husada Surakarta yaitu mengenai Demonstrasi Pengenalan Variasi Menu Diet Diabetes Mellitus Bagi Pendirerita Diabetes Mallitus Tipe 2. Kegiatan ini dilakukan pada periode April - agustus 2020 di Puskesmas Gambirsari.

Pelaksanaan kegiatan pengabdian kepada masyarakat yang meliputi kegiatan demonstasi, monitoring dan evaluasi. Sasaran pada kegiatan ini adalah penderita DM tipe 2 yang berjumlah 25 orang. Pelaksanaan kegiatan pengabdian kepada masyarakat ini dilakukan secara virtual dikarenakan mempertimbangan situasi dan kondisi selama pandemi covid-19. Kegiatan demonstrasi dilakukan melalui video yang dibuat oleh tim pengabdi serta mahasiswa, dan diberikan kepada peserta kegiatan pengabdian kepada masyarakat melalui whatsapp grup. Didalam video tersebut telah menggambarkan mengenai tata cara pembuatan menu dan variasi makanan untuk penderita diabetes melitus tipe 2 . Selain diberikan video, pengabdi juga memberikan penjelasan secara detail mengenai video tersebut, yang diharapkan peserta dapat lebih memahami mengenai variasi menu diet diabetes melitus tipe 2. Pelaksanan kegiatan ini tidak hanya diberikan video demonstrasi, tetapi juga dilakukan kegiatan pretest dan posttest untuk memonitoring dan mengevaluasi kegiatan yang dilakukan dengan menggunakan media whatsapp grup untuk mengamati dan mengukur keberhasilan kegiatan yang dilakukan. Berdasarkan hasil evaluasi yag dilakukan didapatkan nilai rerata pretest sebesar 63, yang menunjukkan bahwa masyarakat kurang memahami mengenai berbagai macam variasi menu untuk diabetes melitus tipe 2. Sebanyak 18 orang memiliki pengetahuan yang kurang, dan 7 orang memiliki pengetahuan yang baik.

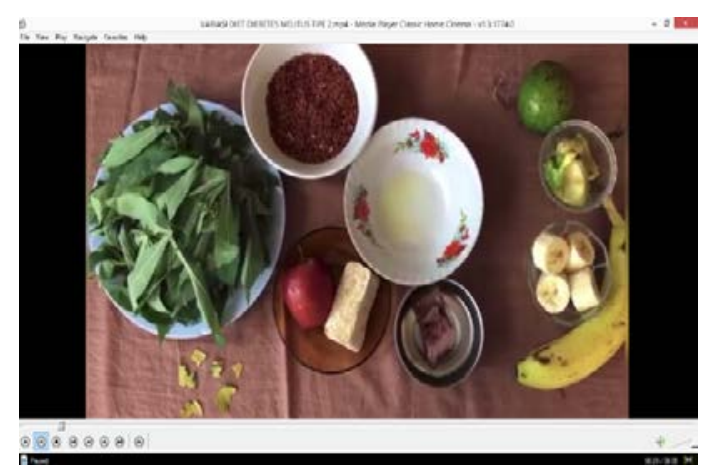

Gambar 1. Bahan makanan yang digunakan dalam pembuatan menu

Setelah dilakukan kegiatan Demonstrasi Pengenalan Variasi Menu Diet Diabetes Mellitus Bagi Pendirerita Diabetes Mallitus Tipe 2, terlihat bahwa 
adanya peningkatan pengetahuan dan keterampilan yang dibuktikan dengan hasil post test sebesar 84, serta bukti foto yang diberikan oleh peserta yang menandakana bahwa peserta sudah mulai memahami bagaimana tata cara dalam pembuatan variasi menu diet diabetes melitus tipe 2. Sebanyak 5 orang memiliki pengetahuan yang kurang dan 20 orang sudah memiliki pengetahuan yang baik. Pengetahuan dikatakan baik jika nilai post test maupun pretest $>70$. Kegiatan pengabdian kepada masyakarat mendapatkan respon positif dari masyarakat. Kegiatan tidak hanya sebatas pemberian video kepada peserta, tetapi peserta juga dapat bertanya dan mengembangkan mengenai resep dalam pengolahan menu untuk diet dabetes melitus tipe 2, dimana sebelumnya belum pernah mendapatkan pengenalan mengenai variasi menu diabetes melitus tipe 2 sebelumnya.

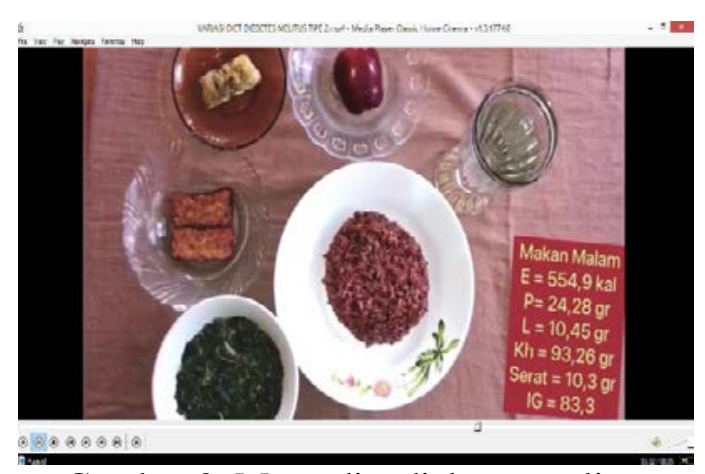

Gambar 2. Menu diet diabetes melitus

Diabetes melitus terdiri dari dua tipe, yaitu diabetes melitus tipe I yang disebabkan oleh keturunan dan tipe II yang disebabkan oleh gaya hidup. Prevalensi DM yang paling banyak adalah Diabetes Melitus Tipe II, ini berarti gaya hidup atau life style yang tidak sehat menjadi pemicu utama meningkatnya prevalensi DM. Selain itu, para penderita DM tipe II seringkali memiliki komplikasi yang dapat menimbulkan kematian (Depkes, 2014). Komplikasi dapat terjadi hampir pada semua bagian tubuh dan dapat menimbulkan risiko kematian secara keseluruhan sebelum waktunya. Komplikasi yang dapat terjadi yaitu serangan jantung, stroke, gagal ginjal, amputasi kaki, kehilangan fungsi penglihatan dan kerusakan fungsi saraf. Maka dari itu penatalaksanaan yang tepat harus dapat dilakukan pada penderita DM untuk mencegah komplikasi yang dapat terjadi.

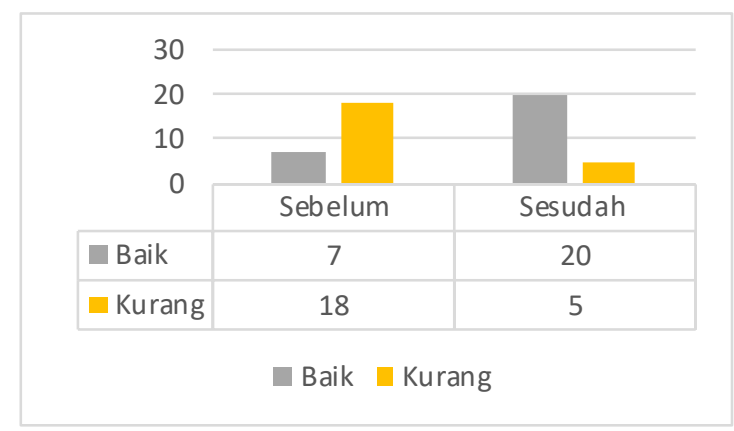

Gambar 3. Tingkat pengetahuan subjek sebelum dan sesudah demonstrasi

Dalam penatalaksanaan diabetes terdapat dua terapi yang dapat dilakukan yaitu terapi farmakologis dan terapi non farmakologis. Terapi non farmakologis dapat dilakukan dengan perubahan gaya hidup dengan pengaturan pola makan, meningkatkan aktivitas jasmani yang berkaitan dengan penyakit DM (Ernawati, 2013). Penelitian lain juga menyebutkan bahwa salah satu terapi non farmakologis yang dapat diterapkan pada pasien DM yaitu pengaturan pola makan atau diet DM, prinsip pengaturan makan pada pasien dengan diabetes yaitu makanan yang seimbang dan sesuai dengan kebutuhan kalori dan zat gizi masing-masing individu, pentingnya keteraturan makan dalam hal jadwal makan, jenis dan jumlah makanan terutama bagi pasien yang 
menggunakan Insulin (Fatimah, 2015). Keberhasilan diet sangat dipengaruhi oleh faktor internal dan faktor eksternal. Faktor internal sebagai penentu keberhasilan diet diantaranya adalah pengetahuan dan sikap.

Penelitian ini sejalan dengan penelitian yang dilakukan oleh Phitri \& Widyaningsih (2013) yang menyatakan bahwa ada hubungan pengetahuan dengan kepatuhan diet (Phitri \& Widyaningsih, 2013). Hasil ini sejalan dengan Ningsih \& Rahma (2018) yang menunjukan adanya hubungan antara pengetahuan dengan tingkat kepatuhan terapi diet pada pasien.

Pengetahuan merupakan hal
yang sangat penting dalam
pembentukan tindakan seseorang
(Ningsih dan Rahma, 2018). Pengetahuan merupakan hasil tahu dan ini terjadi setelah seseorang menggunakan pengindraan terhadap suatu obyek tertentu, pengindraan terhadap obyek yang terjadi melalui panca indra manusia yakni penglihatan, pendengaran, penciuman rasa dan raba sendiri. Pengendalian diabetes dapat dilakukan dengan pengontrolan nutrisi, latihan fisik yang teratur, minum obat anti diabetik atau injeksi insulin, monitoring gula darah, dan mengendalikan stres (Perkeni, 2013).

Pada kegitatan pengabdian kepada masyakat kali ini menggunakan metode demonstrasi, dimana metode demonstrasi lebih mudah untuk menunjukkan pengertian, ide, dan prosedur tentang suatu hal yang pernah dipersiapkan dengan teliti untuk memperlihatkan bagaimana cara melaksanakan suatu tindakan adegan dengan menggunakan alat peraga. Berdasarkan pendapat sanjaya (2008) metode demonstrasi merupakan suatu metode penyajian materi dengan memperagakan dan mempertunjukkan kepada peserta mengenai sesuatu proses, situasi , tertentu baik sebenarnya atau hanya sekedar tiruan. Peran audience saat demonstrasi tidak hanya sekedar memperhatikan tetapi demonstrasi memperagakan kembali tentang materi yang sudah disampaikan sebelumnya. Keuntungan dari metode demonstrasi adalah lebih mudah untuk meningkatkan pengetahuan peserta dan peserta dipandu dalam mengamati serta melakukan secara mandiri (Masturo dkk, 2020).

Selain dapat meningkatkan pengetahuan dengan mudah, keuntungan lain yang didapatkan dari metode demontrasi ini adalah terjadinya verbalisasi, pengamatan melalui peragaan yang di laksanakan. Metode demonstrasi berdasarkan kerucut Edgar Dale berada di tingkat 8 yang menyatakan bahwa dalam proses penyampaian pengetahuan yang mendekati kondisi kenyataan dilapangan akan lebih baik daripada hanya sekedar metode ceramah dan tanya jawab tanpa adanya suatu alat peraga. Metode demonstrasi dalam suatu proses pembelajaran semakin banyak panca indra yang di gunakan dan media pembelajaran yang di guanakan semakin mendekati bentuk asli akan semakin baik hasil belajarnya. Metode demonstrasi dalam mengenalkan variasi menu diet diabetes melitus merupakan cara yang tepat dalam mengajarkan tata cara membuat menu diet untuk penderita diabetes melitus dengan cara yang benar. Karena dengan dengan mempraktekkan tata cara tersebut harapannya para peserta dapat melakukan dengan benar. Dengan meningkatnya kemampuan pengetahuan dan keterampilan yang baik dan benar, bukan hanya dari pengetahuan tetapi dalam pelaksanaannya di harapkan bisa melakukan sendiri sesuai dengan yang telah diperagakan sehingga para peserta bisa melakukannya sendiri secara tepat 
dan bisa menjadi contoh untuk anggota dan rekan yang lain di lingkungan sekitarnya. Dengan adanya tutor maka akan semakin banyak masyarakat yang mengetahui dan memahami bagaimana dan apa saja yang yang harus dipersiapkan untuk membuat menu diet diabetes melitus yang benar (Sukarsih, 2020).

\section{SIMPULAN}

\begin{abstract}
Berdasarkan hasil kegiatan pengabdian kepada masyarakat dengan menggunakan metode demonstrasi mengenai pengenalan variasi menu diet diabetes mellitus bagi penderita diabetes mellitus tipe 2 terlihat bahwa peserta mengalami peningkatan pengetahuan dan pemahaman terhadap materi yang diberikan terbukti dengan adanya peningkatan nilai post test peserta. Untuk pengabdi selanjutnya disarankan adanya pendidikan kesehatan untuk peningkatan pengetahuan secara berkelanjutan dengan metode lain dalam pengenalan variasi menu diet diabetes mellitus bagi penderita diabetes mellitus tipe 2, agar masyarakat dapat lebih memahami dan pengontrol pola makan khususnya bagi penderita diabetes melitus tipe 2
\end{abstract}

\section{UCAPAN TERIMA KASIH}

Diucapkan terimakasih kepada pihak Puskesmas Gambirsari yang telah memberikan kesempatan untuk dilakukan kegiatan pengabdian masyarakat ini sehingga dapat berjalan lancar.

Terimakasih kepada tim dan mahasiswa yang ikut berpartisipasi dalam kegiatan ini, dan tak lupa terimakasih kepada Universitas Kusuma Husada Surakarta yang telah memberikan dukungan penuh sehingga kegiatan ini terlaksana dengan baik.

\section{DAFTAR PUSTAKA}

Badan Penelitian dan Pengembangan
Kesehatan. 2014. Studi Diet

Total : Survei Konsumsi

Makanan Individu. Badan

Penelitian dan

Pengembangan kesehatan

Depkes. 2014. Infodatin. Kementrian kesehatan RI; Pusat data dan informasi.

Ekpenyong, C.E., Udokang, N.E., Akpan, E.E., and Samson, T. 2012. Double

Burden, Non-Communicable Diseases And Risk Factors Evaluation In Sub-Saharan Africa: The Nigerian Experience. European Journal of Sustainable Development, 249-270.

Ernawati. 2013. Penatalaksanaan Keperawatan Diabetes Melitus Terpadu Dengan Penerapan Teori Keperawatan Serlfcare Orem. Jakarta: Mitra Wacana Media.

Fauzia, Y., Sari, E., \& Artini, B. (2015). Gambaran faktor-faktor yang mempengaruhi kepatuhan diet penderita diabetes mellitus di wilayah puskesmas pakis Surabaya. Jurnal

Keperawatan, 4(2).

Feng, L., Li, P., Wang, X., Hu, Z., Ma, Y., Tang, W., and Wang, F. 2014. Distribution and determinants of non communicable diseases among elderly uyghur ethnic group in Xinjiang, China. PLOS ONE. Journal.pone

Kementerian Kesehatan republic Indonesia. 2019. Profil kesehatan Indonesia 2018. Jakarta: Kementerian Kesehatan RI

Kementerian Kesehatan. 2014. Riskesdas 2013. Jakarta (ID): Badan Litbang Kesehatan 
Maryunani, A. 2013. Diabetes pada Kehamilan. Jakarta : Trans Info Media.

Masturo, U., Kholisotin, K., \& Agustin, Y. D. (2020). Efektifitas Penyuluhan Kesehatan tentang SADARI dengan Metode Diskusi Kelompok dan Metode Demonstrasi terhadap Perilaku WUS dalam Melakukan SADARI. Citra Delima: Jurnal Ilmiah STIKES Citra Delima Bangka Belitung, 3(2), 141154.

Murti, Y. L., 2016. Hubungan Antara Kebiasaan Konsumsi Gula Dengan Kejadian Diabetes Mellitus Di Wilayah Kerja Puskesmas Leyangan Ungaran Timur Kabupaten Semarang. Naskah Publikasi

Ngaisyah. Dewi. 2105. Hubungan pola makan dengan tingkat gula darah anggota DPRD propinsi Kalimantan timur. Jurnal Medika Respati 10 (2): 35-46

Ningsih Ropika, Rahma Deni. 2018. Hubungan Pengetahuan Dengan Kepatuhan Diet Pada Pasien Diabetes Mellitus Tipe Ii Di Poliklinik Penyakit Dalam Rsud Dr. Achmad Mochtar Kota Bukittinggi. Nursing Journal of STIKES Insan Cendekia Medika Jombang, Vol.15 No. 1 Maret 2018

Peraturan Menteri Kesehatan RI. 2014. Pedoman Gizi Seimbang.
Menteri Kesehatan Republik indonesia.

Perkeni. 2015. Konsensus pengelolaan dan pencegahan diabetes melitus tipe 2 2015. PB. Perkeni

Phitri, E. 2013. Hubungan Antara Pengetahuan dan Sikap Penderita Diabetes Melitus Dengan Kepatuhan Diet Diabetes Melitus Di RSUD AM. Parikesit Kalimantan Timur. Jurnal Keperawatan Medikal Bedah

Sanjaya wina , 2008 , Strategi Pembelajaran , edisi 8 , Jakarta : Kencana Prenada Media

Santoso, B., Sulistiowati, E., Fajarwati, T., dan Pambudi, J. 2014. Studi Diet Total: Survei Konsumsi Makanan Individu Provinsi Jawa Tengah. Badan Penelitian Dan Pengembangan Kesehatan, 18-22.

Subyantoro G, 2012, Kebijakan pengendalian penyakit tidak menular. Seminar nasional keperawatan. Univeristas Muhammadiyah Surakarta.

Sukarsih, R. I. 2020. Pengaruh Metode Demonstrasi Terhadap Perilaku Sadari Sebagai Upaya Deteksi Dini Kanker Payudara Di Puskesmas Kedurus. Sinar: Jurnal Kebidanan, 1(1). 